\title{
Maize Growth and Yield Response to Different Rates of Humic Acid and Zinc
}

\author{
Mahmud A. A.Rahouma ${ }^{1}$
}

\begin{abstract}
To study humic acid and zinc effect on maize (Zea mays L.) growth, yield and its attributes, a field experiment was set up during 2021 summer season in a Private Farm at Al-Maamorah district, El-Ghafara, Tripoli, Lybia. Randomized complete block design with split-arrangement in three replicates was used. Four humic acid levels, i.e. control (without humic acid), 5, 10 and $15 \mathrm{~kg} / \mathrm{ha}$ were randomly distributed as main plots, while four zinc concentrations $(0,3,6$ and $9 \mathrm{ml} / \mathrm{l})$ were allocated in the sub-plots. Pioneer 3084 maize plants treated with humic acid significantly surpassed, in all growth, yield, yield components and grain protein content traits, than the control treatment. The same trend was found for zinc foliar application, except for ear length. Soil application of $15 \mathrm{~kg}$ humic acid per hectare combined with $9 \mathrm{ml}$ zinc/ $\mathrm{l}$ as foliar application produced the highest values for ear leaf area $\left(\mathbf{1 0 0 0 . 1 7} \mathrm{cm}^{2}\right)$, plant height $(240.56$ $\mathrm{cm})$, stem and ear diameters $(2.20 \mathrm{~cm}$ and $4.52 \mathrm{~cm}$, respectively), tallest ears $(25.19 \mathrm{~cm})$, number of rows/ ear (14.62), number of kernels/ row (54.13), shelling percentage $(82.17 \%)$, 100-kernel weight $(41.83 \mathrm{~g})$, grain yield (7.192 t/ ha) and grain protein content $(10.17 \%)$.
\end{abstract}

Key words: maize, growth, grain yield, grain protein, humic acid, zinc concentrations.

\section{INTRODUCTION}

Maize (Zea mays L.) is one of the most important cereal crops that belong to family Gramineae (Poaceae), where it takes the third rank after wheat and rice in terms of acreage and production in the world (Taha et al., 2019). Maize grains contain $81 \%$ carbohydrates, $10.6 \%$ protein, $4.6 \%$ oil, $2 \%$ ash and $\mathrm{E}, \mathrm{B}_{1}, \mathrm{~B}_{2}$ vitamins. Hence, it is used for feeding livestock as green fodder (silage), poultry as concentrated diets, medical industry as a treatment for kidney stones, reduces blood pressure and sugar. Also, it is used in biofuel, paper and starch industries (Ayyar et al., 2019). This crop has high productive ability compared to wheat and rice, and is grown in more than 130 countries (Suganya and Saravanan, 2015). From the physiological view, maize is a $\mathrm{C}_{4}$ plant that can convert the absorbed nutrients to dry matter efficiently, so it is a high nutrient demanding crop and it is very sensitive to zinc deficiency, therefore, Ayyar and Appavoo (2017) considered it as an indicator plant of zinc deficiency. Dowswell (2019) reported that average maize grain yield in developed and developing countries are (6.2 and $2.5 \mathrm{t} / \mathrm{ha}$ ), respectively, and this discrepancy may be due to technological, environmental and organization of crop. Many researchers such as Tahir et al. (2011) and AlMahdi et al. (2021), Kamh and Hedia (2018) and Humintech (2012) reported that humic acid is very important for plant growth, mineral nutrition, uptake of macro and micronutrients and reducing the uptake of some toxic elements. Humic acid, also could counteract abiotic stress conditions as $\mathrm{pH}$, salinity and unfavourable air temperature (Masciandaro et al., 2002). On the other hand, zinc is considered the most important trace elements for human health. Zinc plays a key role for regulation of many enzymes related with carbohydrate, protein and auxin metabolism and conversion of sugar to starch, grain formation besides resistance to pathogens infection (Sadeghzadeh, 2013 and $\mathrm{Hu}$ and Wenjiao, 2015). High soil $\mathrm{pH}$, organic matter deficit, higher carbonate content, extra phosphate fertilizer application, absorption ability of micro nutrients will be reduced and consequently maize growth and yield will be decreased. So, the objectives of this research were to study the effects of both humic acid levels and zinc concentrations beside their interaction on maize growth, yield and yield components.

\section{MATERIALS AND METHODS}

This trial was carried out during 2021 summer season in a Private Farm of Al-Maamorah district, ELGhafara, Tripoli, Libya to study humic acid levels and zinc concentrations effect on maize (Zea mays L.) growth, grain yield, yield components and grain protein content using randomized complete block design with three replications in a split-plot arrangement. Single cross Pioneer 3084 (yellow seeds) was used and the preceding crop was bread wheat.

Soil samples were collected before sowing from 0$30 \mathrm{~cm}$ depth of the experimental site to determine soil chemical and physical properties according to Page et al. (1982). Full analysis of soil samples are presented in Table (1). 
Table 1. Soil physical and chemical properties of experimental site

\begin{tabular}{|c|c|c|c|}
\hline \multicolumn{4}{|c|}{ Physical properties } \\
\hline Sandy $(\%)$ & 88.8 & Silt $(\%)$ & 6.6 \\
\hline Clay $(\%)$ & 4.6 & Texture & Sandy \\
\hline \multicolumn{4}{|c|}{ Chemical properties } \\
\hline $\mathrm{N}(\%)$ & 0.024 & $\mathrm{Ca}^{++}$ & 1.96 \\
\hline $\mathrm{P}(\mathrm{ppm})$ & 26.6 & $\mathrm{Cl}^{-}(\mathrm{meq} / \mathrm{l})$ & 1.20 \\
\hline $\mathrm{K}(\mathrm{ppm})$ & 83.7 & $\mathrm{Mg}^{++}(\mathrm{meq} / \mathrm{l})$ & 3.22 \\
\hline Ec $(\mathrm{dS} / \mathrm{m})$ & 0.76 & $\mathrm{Na}^{+}(\mathrm{meq} / \mathrm{l})$ & 2.02 \\
\hline $\mathrm{pH}$ & 7.7 & $\mathrm{Fe}^{++}(\mathrm{ppm})$ & 2.90 \\
\hline O.M. $(\%)$ & 1.67 & $\mathrm{Zn}^{++}(\mathrm{ppm})$ & 2.50 \\
\hline
\end{tabular}

Four humic acid levels, i.e. $0,5,10$ and $15 \mathrm{~kg} / \mathrm{ha}$, as soil application, were randomly distributed as whole plots, while four zinc sulphate $\left(\mathrm{ZnSO}_{4} .7 \mathrm{H}_{2} \mathrm{O}\right)$ concentrations, i.e. $0,3,6$ and $9 \mathrm{ml} / 1$ were assigned as sub-plots. Sub-plot area was $9 \mathrm{~m}^{2}$ (5 ridges each $3 \mathrm{~m}$ length and $0.6 \mathrm{~m}$ width). Sowing date was mid June at seeding rate of $30 \mathrm{~kg} / \mathrm{ha}$. Nitrogen was applied at the rate of $285 \mathrm{~kg} / \mathrm{ha}$ as urea $(46 \%)$ in two equal doses applied just before the first and second irrigations after sowing. Phosphorus, was also applied at the rate of 38 $\mathrm{kg} / \mathrm{ha}$ as calcium monophosphate $\left(15.5 \% \mathrm{P}_{2} \mathrm{O}_{5}\right)$ during seed bed preparation, however potassium as potassium sulphate $\left(48 \% \mathrm{~K}_{2} \mathrm{O}\right)$ was applied at the rate of $57.6 \mathrm{~kg}$ $\mathrm{K}_{2} \mathrm{O} /$ ha at 30 days after sowing (30 DAS). Humic acid was applied to the soil at 30 DAS, however zinc was applied at 30 and 45 DAS as foliar application. Other cultural practices for maize production were carried out as recommended. At harvest, five guarded plants were randomly chosen to determine ear leaf area $\left(\mathrm{cm}^{2}\right)$, plant height $(\mathrm{cm})$, stem diameter $(\mathrm{cm})$, ear length and diameter $(\mathrm{cm})$, number of rows/ ear and number of kernels/ row, shelling percentage and 100-kernel weight $(\mathrm{g})$. Grain yield ( $\mathrm{t} / \mathrm{ha}$ ) was calculated by harvesting the three inner rows $(\mathrm{kg})$ in each sub-plot and transferred to (t/ ha) and grain protein content was determined according to A.O.A.C. (1990).

Collected data were statistically analyzed according to Gomez and Gomez (1984). Least significant differences at 0.05 probability level (L.S.D.0.05) was used to compare the difference between means of the studied treatments.

\section{RESULTS AND DISCUSSION}

Results presented results in Table (2) revealed that all studied growth characters, yield and its components and grain protein content of Pioneer 3084 maize variety were significantly affected by humic acid application rates, zinc concentrations and their interactions, except zinc concentrations effect on ear length. With respect to humic acid effect, data showed that increasing humic acid rates significantly and gradually increased all the studied traits of maize and the highest level $(15 \mathrm{~kg} / \mathrm{ha})$ produced the highest ear leaf area $\left(989.75 \mathrm{~cm}^{2}\right)$, tallest plants and ears $(234.10$ and $24.35 \mathrm{~cm}$, respectively), thicker stalks and ears (2.13 and $4.26 \mathrm{~cm}$, respectively), highest number of rows/ ear (14.31), number of kernels/ row (52.17), shelling percentage $(81.10 \%)$, grain yield $(6.948 \mathrm{t} / \mathrm{ha})$, grain protein content $(10.04 \%)$ and heaviest 100-kernel weight (41.21 g). Humic acid had significant and positive effect on all growth and yield characters of maize crop and that could be due to its effects in improving soil physical and chemical properties and increasing absorption of ammonium, potassium and zinc that lead to accelerate the biological processes in plants such as photosynthesis to produce sugars (Shahryari et al., 2011; Taj El-Deen and AlBarakat, 2017 and Mahmood et al., 2020). Similar results were reported by Shahryari et al. (2011) for plant height, Tahir et al. (2011) and Daur and Bakhashwain (2013) for leaf area. Increasing grain yield and its components as a result of increasing humic acid level up to $15 \mathrm{~kg} /$ ha might be due to the increase of ear leaf area and increasing light interception and photosynthesis activity and consequently increased in ear characters as ear length (El-Hady et al., 2017 and Al-Rawi and AlDulaimi, 2021), number of rows/ ear (Abdullah et al., 2019), number of grains/ row (El-Shafey and Zen ElDein, 2016), 100-kernel weight (Khan et al., 2019), total grain yield (El-Rawi and Al-Dulaimi, 2021) and grain protein content (Daur and Bakhashwain, 2013).

Regarding zinc application effect on maize plant growth, yield and its components and quality, results presented in Table (2) showed that spraying maize plants with zinc concentrations up to $9 \mathrm{ml} / 1$ significantly and gradually increased plant growth, yield and quality, except ear length, where increases did not reach significance level. Zinc foliar application, generally increased growth, grain yield and yield attributes, 
Table 2. Means of growth characters, grain yield, yield attributes and grain protein content as affected by humic acid and zinc levels application

\begin{tabular}{|c|c|c|c|c|c|c|c|c|c|c|c|}
\hline Treatment & $\begin{array}{c}\text { Ear leaf } \\
\text { area } \\
\left(\mathrm{cm}^{2}\right)\end{array}$ & $\begin{array}{c}\text { Plant } \\
\text { height } \\
\text { (cm) }\end{array}$ & $\begin{array}{c}\text { Stem } \\
\text { diameter } \\
(\mathrm{cm})\end{array}$ & $\begin{array}{c}\text { Ear } \\
\text { length } \\
\text { (cm) }\end{array}$ & $\begin{array}{c}\text { Ear } \\
\text { diameter } \\
(\mathbf{c m})\end{array}$ & $\begin{array}{c}\text { No. of } \\
\text { rows/ } \\
\text { ear }\end{array}$ & $\begin{array}{c}\text { No. of } \\
\text { kernels/ } \\
\text { row }\end{array}$ & $\begin{array}{c}\text { Shelling } \\
\%\end{array}$ & $\begin{array}{c}\text { 100- } \\
\text { kernel } \\
\text { weight } \\
\text { (g) }\end{array}$ & $\begin{array}{c}\text { Grain } \\
\text { yield } \\
\text { (t/ ha) }\end{array}$ & $\begin{array}{c}\text { Protein } \\
(\%)\end{array}$ \\
\hline \multicolumn{12}{|l|}{ Humic kg/ ha } \\
\hline 0 & $823.48 \mathrm{~d}$ & $210.44 \mathrm{c}$ & $1.54 \mathrm{~d}$ & $20.26 \mathrm{c}$ & $3.50 \mathrm{~d}$ & $12.66 \mathrm{~d}$ & $35.81 \mathrm{c}$ & $75.84 \mathrm{~d}$ & $36.59 \mathrm{~d}$ & $4.208 \mathrm{~d}$ & $8.00 \mathrm{~d}$ \\
\hline 5 & $906.91 \mathrm{c}$ & $220.05 \mathrm{~b}$ & $1.76 \mathrm{c}$ & $21.54 \mathrm{c}$ & $3.83 \mathrm{c}$ & $13.41 \mathrm{c}$ & $38.57 \mathrm{c}$ & $77.24 \mathrm{c}$ & $37.61 \mathrm{c}$ & $5.335 \mathrm{c}$ & $8.50 \mathrm{c}$ \\
\hline 10 & $935.27 \mathrm{~b}$ & $223.76 \mathrm{~b}$ & $1.96 \mathrm{~b}$ & $23.30 \mathrm{~b}$ & $4.16 \mathrm{~b}$ & $13.83 \mathrm{~b}$ & $45.15 \mathrm{~b}$ & $79.52 \mathrm{~b}$ & $39.37 \mathrm{~b}$ & $6.363 \mathrm{~b}$ & $9.51 \mathrm{~b}$ \\
\hline 15 & $989.75 \mathrm{a}$ & $234.10 \mathrm{a}$ & $2.13 \mathrm{a}$ & $24.35 \mathrm{a}$ & $4.26 \mathrm{a}$ & $14.31 \mathrm{a}$ & $52.17 \mathrm{a}$ & $81.10 \mathrm{a}$ & $41.21 \mathrm{a}$ & $6.948 \mathrm{a}$ & $10.04 \mathrm{a}$ \\
\hline \multicolumn{12}{|l|}{ Zinc $\mathrm{ml} / \mathrm{l}$} \\
\hline 0 & $888.43 c$ & $213.74 \mathrm{~d}$ & $1.74 \mathrm{~d}$ & $21.64 \mathrm{a}$ & $3.78 \mathrm{~d}$ & $13.23 \mathrm{~d}$ & $41.65 \mathrm{~b}$ & $77.48 \mathrm{~d}$ & $38.07 \mathrm{~d}$ & $5.375 \mathrm{c}$ & $8.76 \mathrm{~d}$ \\
\hline 3 & $906.88 \mathrm{~b}$ & $219.14 \mathrm{c}$ & $1.83 \mathrm{c}$ & $22.18 \mathrm{a}$ & $3.87 \mathrm{c}$ & $13.46 \mathrm{c}$ & $42.60 \mathrm{ab}$ & $78.12 \mathrm{c}$ & $38.45 \mathrm{c}$ & $5.633 \mathrm{~b}$ & $8.97 \mathrm{c}$ \\
\hline 6 & $913.70 \mathrm{~b}$ & $225.00 \mathrm{~b}$ & $1.88 \mathrm{~b}$ & $22.64 \mathrm{a}$ & $4.01 \mathrm{~b}$ & $13.68 \mathrm{~b}$ & $42.88 \mathrm{ab}$ & $78.74 \mathrm{~b}$ & $38.96 \mathrm{~b}$ & $5.814 \mathrm{~b}$ & $9.10 \mathrm{~b}$ \\
\hline 9 & $946.62 \mathrm{a}$ & $230.38 \mathrm{a}$ & $1.94 \mathrm{a}$ & $22.99 \mathrm{a}$ & $4.11 \mathrm{a}$ & $13.85 \mathrm{a}$ & $44.56 \mathrm{a}$ & $79.36 \mathrm{a}$ & $39.30 \mathrm{a}$ & $6.032 \mathrm{a}$ & $9.22 \mathrm{a}$ \\
\hline $\begin{array}{l}\text { Interaction } \\
\mathrm{H}^{*} \mathrm{Zn}\end{array}$ & $*$ & $* *$ & $*$ & $* *$ & $*$ & $* *$ & $*$ & $*$ & $* *$ & $* *$ & $*$ \\
\hline
\end{tabular}

* significant at 0.05 level of probability.

** significant at 0.01 level of probability.

Means followed by the same letter(s) within each column are not statically different according to L.S.D.0.05 values. 
Table 3. Means of growth charcaters, grain yield, yield attributes and grain protein content as affected by humic acid $\times$ zinc levels interaction

\begin{tabular}{|c|c|c|c|c|c|c|c|c|c|c|c|c|}
\hline $\begin{array}{c}\text { Humic } \\
\text { (kg/ ha) }\end{array}$ & $\begin{array}{c}\text { Zinc } \\
(\mathrm{ml} / \mathrm{l})\end{array}$ & $\begin{array}{c}\text { Ear leaf area } \\
\left(\mathrm{cm}^{2}\right)\end{array}$ & $\begin{array}{c}\text { Plant } \\
\text { height } \\
\text { (cm) }\end{array}$ & $\begin{array}{c}\text { Stem } \\
\text { diameter } \\
(\mathrm{cm})\end{array}$ & $\begin{array}{c}\text { Ear } \\
\text { length } \\
(\mathrm{cm})\end{array}$ & $\begin{array}{c}\text { Ear } \\
\text { diameter } \\
(\mathbf{c m})\end{array}$ & $\begin{array}{c}\text { No. of } \\
\text { rows/ ear }\end{array}$ & $\begin{array}{l}\text { No. of } \\
\text { kernels/ } \\
\text { row }\end{array}$ & Shelling \% & $\begin{array}{c}100- \\
\text { kernel } \\
\text { weight (g) }\end{array}$ & $\begin{array}{c}\text { Grain } \\
\text { yield } \\
\text { (t/ ha) }\end{array}$ & $\begin{array}{c}\text { Protein } \\
(\%)\end{array}$ \\
\hline \multirow{4}{*}{0} & 0 & $784.55 \mathrm{e}$ & $201.55 \mathrm{~d}$ & $1.44 \mathrm{f}$ & $19.59 \mathrm{e}$ & $3.33 \mathrm{~h}$ & $12.18 \mathrm{k}$ & $34.74 \mathrm{~g}$ & $74.13 \mathrm{k}$ & $36.0 \mathrm{n}$ & $3.809 \mathrm{~m}$ & 7.841 \\
\hline & 3 & 808.19 de & $208.68 \mathrm{~cd}$ & $1.52 \mathrm{f}$ & $20.06 \mathrm{e}$ & $3.42 \mathrm{~h}$ & $12.52 \mathrm{j}$ & $35.19 \mathrm{~g}$ & $75.62 \mathrm{j}$ & $36.27 \mathrm{~m}$ & 4.0701 & $8.00 \mathrm{k}$ \\
\hline & 6 & $817.08 \mathrm{~d}$ & $212.87 \mathrm{c}$ & $1.59 \mathrm{e}$ & $20.47 \mathrm{de}$ & $3.56 \mathrm{~g}$ & $12.89 \mathrm{i}$ & $36.07 \mathrm{fg}$ & $76.47 \mathrm{i}$ & 36.891 & $4.363 \mathrm{k}$ & $8.06 \mathrm{k}$ \\
\hline & 9 & $884.13 \mathrm{c}$ & $218.67 \mathrm{bc}$ & $1.62 \mathrm{de}$ & $20.95 \mathrm{de}$ & $3.72 \mathrm{f}$ & $13.07 \mathrm{~h}$ & $37.25 \mathrm{f}$ & $77.14 \mathrm{~h}$ & $37.22 \mathrm{k}$ & $4.591 \mathrm{j}$ & $8.10 \mathrm{k}$ \\
\hline \multirow{5}{*}{5} & 0 & $880.62 \mathrm{c}$ & $210.78 \mathrm{~cd}$ & $1.63 \mathrm{de}$ & $21.00 \mathrm{~d}$ & $3.74 \mathrm{f}$ & $13.10 \mathrm{~h}$ & $37.66 \mathrm{f}$ & $76.67 \mathrm{i}$ & $37.05 \mathrm{k}$ & $4.968 \mathrm{i}$ & $8.28 \mathrm{j}$ \\
\hline & 3 & $897.14 \mathrm{c}$ & $219.69 \mathrm{bc}$ & $1.70 \mathrm{~d}$ & $21.25 \mathrm{~cd}$ & $3.80 \mathrm{ef}$ & $13.34 \mathrm{~g}$ & $38.00 \mathrm{f}$ & $77.10 \mathrm{~h}$ & $37.43 \mathrm{j}$ & $5.210 \mathrm{~h}$ & $8.40 \mathrm{i}$ \\
\hline & 6 & $910.36 \mathrm{c}$ & $222.60 \mathrm{bc}$ & $1.82 \mathrm{c}$ & $21.84 \mathrm{~cd}$ & $3.87 \mathrm{e}$ & $13.52 \mathrm{f}$ & $38.02 \mathrm{f}$ & $77.22 \mathrm{~h}$ & $37.90 \mathrm{i}$ & $5.446 \mathrm{~g}$ & $8.54 \mathrm{~h}$ \\
\hline & 9 & $939.54 \mathrm{bc}$ & $227.13 \mathrm{~b}$ & $1.89 \mathrm{c}$ & $22.09 \mathrm{c}$ & $3.92 \mathrm{de}$ & $13.70 \mathrm{ef}$ & $42.60 \mathrm{e}$ & $78.00 \mathrm{~g}$ & $38.08 \mathrm{i}$ & $5.717 \mathrm{f}$ & $8.79 \mathrm{~g}$ \\
\hline & 0 & $909.22 \mathrm{c}$ & $213.54 \mathrm{c}$ & $1.83 \mathrm{c}$ & $22.89 \mathrm{bc}$ & $4.01 \mathrm{~d}$ & $13.62 \mathrm{f}$ & $44.10 \mathrm{~d}$ & $78.87 \mathrm{f}$ & $38.57 \mathrm{~h}$ & $6.009 \mathrm{e}$ & $9.00 \mathrm{f}$ \\
\hline \multirow{2}{*}{10} & 6 & $934.17 \mathrm{bc}$ & $226.20 \mathrm{~b}$ & $2.02 \mathrm{~b}$ & $23.48 \mathrm{~b}$ & $4.22 \mathrm{bc}$ & $13.92 \mathrm{~d}$ & $45.09 \mathrm{~cd}$ & $79.86 \mathrm{~d}$ & $39.72 \mathrm{f}$ & $6.437 \mathrm{~cd}$ & $9.76 \mathrm{~d}$ \\
\hline & 9 & $962.65 \mathrm{~b}$ & $235.17 \mathrm{ab}$ & $2.05 \mathrm{~b}$ & $23.76 b$ & $4.30 \mathrm{~b}$ & $14.02 \mathrm{~d}$ & $46.27 \mathrm{c}$ & $80.12 \mathrm{~d}$ & $40.09 \mathrm{e}$ & $6.628 \mathrm{c}$ & $9.83 \mathrm{~d}$ \\
\hline \multirow{3}{*}{15} & $\begin{array}{l}0 \\
3\end{array}$ & $\begin{array}{l}979.36 \mathrm{ab} \\
987.14 \mathrm{ab}\end{array}$ & $\begin{array}{l}229.09 \mathrm{~b} \\
228.52 \mathrm{~b}\end{array}$ & $\begin{array}{c}2.09 \mathrm{~b} \\
2.13 \mathrm{ab}\end{array}$ & $\begin{array}{c}23.11 \mathrm{~b} \\
24.34 \mathrm{ab}\end{array}$ & $\begin{array}{c}4.04 \mathrm{~cd} \\
4.15 \mathrm{c}\end{array}$ & $\begin{array}{l}14.02 \mathrm{~d} \\
14.23 \mathrm{c}\end{array}$ & $\begin{array}{c}50.13 \mathrm{~b} \\
52.09 \mathrm{ab}\end{array}$ & $\begin{array}{c}80.26 \mathrm{~cd} \\
80.53 \mathrm{c}\end{array}$ & $\begin{array}{l}40.66 \mathrm{~d} \\
41.00 \mathrm{c}\end{array}$ & $\begin{array}{c}6.715 b c \\
6.873 b\end{array}$ & $\begin{array}{c}9.94 \mathrm{c} \\
10.00 \mathrm{bc}\end{array}$ \\
\hline & 6 & $992.34 \mathrm{ab}$ & $238.24 \mathrm{ab}$ & $2.10 \mathrm{~b}$ & $24.78 \mathrm{a}$ & $4.33 \mathrm{~b}$ & $14.40 \mathrm{~b}$ & $52.36 \mathrm{a}$ & $81.44 \mathrm{~b}$ & $41.35 \mathrm{~b}$ & $7.012 \mathrm{ab}$ & $10.05 \mathrm{~b}$ \\
\hline & 9 & $1000.17 \mathrm{a}$ & $240.56 \mathrm{a}$ & $2.20 \mathrm{a}$ & $25.19 \mathrm{a}$ & $4.52 \mathrm{a}$ & $14.62 \mathrm{a}$ & $54.13 \mathrm{a}$ & $82.17 \mathrm{a}$ & $41.83 \mathrm{a}$ & $7.192 \mathrm{a}$ & $10.17 \mathrm{a}$ \\
\hline
\end{tabular}

Means followed by the same letter(s) within each column are not statically different according to L.S.D.0.05 values. 
beside grain protein content of Pioneer 3084 maize variety compared with untreated plants with zinc (control). That could be due to the essential effect of zinc for normal healthy growth and reproduction of plants. Marschner (1995) reported that this micro element has important roles in plant growth regulation, photosynthesis, protein synthesis, carbohydrate metabolism, flowers fertility and seed production, beside its importance for disease protection. On the other hand, zinc deficiency in soil of the experimental site might be due to higher $\mathrm{pH}$ above 6.5 and low organic matter content as shown in Table (1), so zinc foliar application led to increase in all the studied traits (Table 2). Results presented in that table showed that maize plants spraying with $9 \mathrm{ml}$ zinc/ 1 produced the highest area of ear leaf $\left(946.62 \mathrm{~cm}^{2}\right)$, tallest plants $(230.38 \mathrm{~cm})$, highest stalk and ear diameters $(1.94$ and $4.11 \mathrm{~cm})$, highest number of rows/ ear (13.85), kernels/ row (44.56), shelling percent (79.36), heaviest 100kernel weight $(39.30 \mathrm{~g})$, highest grain yield (6.032 t/ ha) and grain protein content $(9.22 \%)$. These results were confirmed by Mortvedth (2003) for leaf area index (LAI), Safyan et al. (2012) for plant height, Firouzi (2005) for ear diameter, Tahir et al. (2009) for 100kernel weight and grain protein content and Rajaie and Ziaeyan (2009) for grain yield.

Interaction between humic acid levels and zinc concentrations effect on maize plant growth, grain yield, yield components and grain protein content were significant as shown in Table (3). Presented results in that table, generally demonstrated that untreated plants with both humic acid and zinc sulphate showed the lowest ear leaf area $\left(784.55 \mathrm{~cm}^{2}\right)$, shortest plants $(201.55 \mathrm{~cm})$, lowest stem diameter $(1.44 \mathrm{~cm})$, number of rows/ ear (12.18), shelling percent $(74.13 \%)$, grain yield $(3.809 \mathrm{t} / \mathrm{ha})$, grain protein content $(7.84 \%)$ and lightest 100-kernel weight $(36.0 \mathrm{~g})$. However, the aforementioned control and zinc foliar application at 3 $\mathrm{ml} / 1$ produced the shortest ears $(19.59$ and $20.06 \mathrm{~cm})$, lowest ear diameter $(3.42 \mathrm{~cm})$ and number of kernels/ row (35.19), respectively.

On the contrast, the highest humic acid level $(15 \mathrm{~kg} /$ ha) combined with 6 or $9 \mathrm{ml} / 1$ of zinc sulphate produced the tallest ears $(24.78$ and $25.19 \mathrm{~cm})$ and highest number of kernels/ row (52.36 and 54.13), respectively. On the other hand, maize plants treated with combinations of $15 \mathrm{~kg}$ humic acid per hectare and $9 \mathrm{ml}$ of $\mathrm{ZnSO}_{4} .7 \mathrm{H}_{2} \mathrm{O}$ per litre produced the highest ear leaf area $\left(1000.17 \mathrm{~cm}^{2}\right)$, plant height $(240.56 \mathrm{~cm})$, stem and ear diameters $(2.20$ and $4.52 \mathrm{~cm})$, number of rows/ ear (14.62), shelling percent $(82.17 \%)$, grain yield $(7.192 \mathrm{t} / \mathrm{ha})$, grain protein content $(10.17 \%)$ and heaviest 100-kernel weight (41.83 g). That could be related to humic acid improving effect of soil properties as decreasing $\mathrm{pH}$ and increasing absorption of ammonium, potassium and micro elements (Taj AlDeen et al., 2017). These acceleration effect of the active absorption of plant roots combined with the essential effect of zinc on plant growth, fertility, kernel production, photosynthesis, protein synthesis and carbohydrate metabolism were reflected in better plant growth and higher yield (Marschner, 1995).

\section{CONCLUSION}

Both humic acid and zinc application have significantly improved Pioneer 3084 maize plant growth, grain yield, yield attributes and grain protein content under Al-Maamorah district, El-Ghafara, Tripoli conditions. The best results have been recorded with 15 $\mathrm{kg}$ humic acid/ ha as soil application combined with spraying of $9 \mathrm{ml} / 1$ zinc as foliar application.

\section{REFERENCE}

A.O.A.C. 1990. Association of Official Analysis Chemists. $13^{\text {th }}$ ed., Washington, D.C., USA.

Abdullah, T.A., M.J. Al-Laila and Kh.S. Abdullah. 2019. The effect of humic acid and plant density on yield of two cultivars of yellow corn (Zea mays L.). Kirkuk Univ. J. Agric. Sci. 888-904.

Al-Rawi, O.Y.A. and O.I.M. Al-Dulaimi. 2021. The effect of humic acid addition stages and planting times in some components and yield of Zea mays L. Earth and Environ. Sci.761 (1): 012078.

Al-Mahdi, I.O., S.Sh. EL-Tabbakh., A.I. Nawar and M.H. Abd-Elmoneim. 2021. Yield and Yield Components of Durum Wheat as Influenced by Humic Acid, Zinc and Iron Application. Alex. Sci. Exch. J. 42: 107-120.

Ayyar, S. and S.Appavoo. 2017. Effect of graded levels of Zn in combination with or without microbial inoculation on $\mathrm{Zn}$ transformation in soil, yield and nutrient uptake by maize in black soil. Environ. \& Ecol. 35 (1): 172- 176.

Ayyar, S., S.Appavoo, M. Basker, P. Pandiyarajan and R. Kavimani. 2019. Effect of zinc and microbial inoculation on soil enzyme activities of maize (Zea mays L.) in black soil. Int. J. Curr. Micro. Appl. Sci. 8 (8): 1804- 1814.

Daur, I. and A.A. Bakhashwain. 2013. Effect of humic acid on growth and quality of maize fodder production. Pak. J. Bot. 45 (S1): 12-15.

Dowswell, C. 2019. Maize in The Third World. $1^{\text {st }}$ ed., CRC press.

El-Hady, A., M.A. Fergany and M. El-Temsah. 2017. Influence of integration between mineral nitrogen and humic acid fertilizers on productivity and nitrogen partitioning dynamic in maize plants. Egypt. J. Agron. 39 (2): 195-202.

El-Shafey, A.I. and A.A. Zen El-Dein. 2016. Response of maize intercropping with soybean to nitrogen fertilizer and humic acid application. J. Plant Prod. 7 (7): 733- 741. 
Firouzi, M. 2005. The effect of foliar absorption of microelements on growth and yield of foliage corn. MS thesis in Agron., Agric. Coll., Islamic Azad Univ., Khorasgan Brach.

Gomez, K.A. and A.A. Gomez. 1984. Statistical Procedures for Agricultural Research. $2^{\text {nd }}$ ed. John Wiley and Sons. New York, USA.

$\mathrm{Hu}, \mathrm{Z}$. and Z. Wenjiao. 2015. Effects of zinc stress on growth and antioxidant enzyme responses of Kandelia obovate seedlings. Toxicol. Environ. Chem. 97: 1190-1201.

Humintech. 2012. Is it possible to replace humus with organic manure? http://www.humintech.com/001/industry/information/faq. html=top (accessed 02 Feb.).

Khan, S.A, S.U. Khan, A. Qayyum, A.R. Gurmani, A. Khan, S.M. Khan and A.Z. Amin. 2019. Integration of humic acid with nitrogen wields an auxiliary impact on physiological traits, growth and yield of maize (Zea mays L.) varieties. Appl. Ecol. Environ. Res.17 (3): 6783- 6799.

Mahmood, Y.A., F.W. Ahmed, Iman Q. Mohammed and K.A. Wheib. 2020. Effect of organic, mineral fertilizers and foliar application of humic acid on growth and yield of corn (Zea mays L.). Ind. J. Eco. 47 (10): 39-44.

Marschner, H. 1995. Mineral Nutrition of High Plant. Pp. 330355. Academic Press, UK.

Masciandaro, G., B. Ceccanti, V. Ronchi, S. Benedicto and L. Howard. 2002. Humic substances to reduce salt effect on plant germination and growth. Comm. Soil Sci. Plant Anal. 33: 365- 378.

Mortvedth, J. 2003. Efficient Fertilizer Use Micronutrients. P. 16. Florida Univ. Published.

Page, A.L., R.H. Miller and D.R. Keeney. 1982. Methods of Soil Analysis. $2^{\text {nd }}$ ed. American Society of Agronomy, Madison, WI, USA.

Rajaie, M. and A.H. Ziaeyan. 2009. Combined effect of zinc and boron on yield and nutrients accumulation in corn. Int. J. Plant Prod. 3 (3): 35-44.
Sadeghzadeh, B. 2013. A review of zinc nutrition and plant breeding. J. Soil Sci. Plant Nut. 13: 309-327.

Safyan, Nassrin, M.R. Naderidarbaghshahi and B. Bahari. 2012. The effect of microelements spraying on growth, qualitative and quantitative grain corn in Iran. Int. Res. J. App. Basic Sci. 3 (S): 2780- 2784.

Shahryari, R., M. Khayatnezhad and N. Bahari. 2011. Effect of two humic fertilizers on germination and seedling growth of maize genotypes. Advances Environ. Bio. 43: 114-118.

Suganya, A. and A. Saravanan. 2015. DTPA-Zn in pH varied soils under simulated moisture conditions as influenced by graded levels of $\mathrm{Zn}$ in combination with $\mathrm{Zn}$ solubilizing bacteria. Trends in Bioscience. 8: 812- 815.

Taha, A.A., M.J. Al-Laila and K.S. Abdullah. 2019. The effect of humic acid and plant density on growth and yield of two cultivars of yellow corn (Zea mays L.). 2- Quotient adjectives. Kirkuk Univ. J. Agric. Sci., 2018 (special Issue). 888-904.

Tahir, M.M., M. Khurshid, M.Z. Khan, M.K. Abbasi and M.H. Kazmi. 2011. Lignite-derived humic acid effect on growth of wheat plants in different soils. Pedosphere. 21 (1): 124-131.

Tahir, M.M., N. Fiaz, M.A. Nadeem, F. Khalid and M. Ali. 2009. Effect of different chelated zinc source on the growth and yield of maize (Zea mays L.). Soil \& Environ. 28 (2): 179-183.

Taj El-Deen, M.M. and H.N.K. Al-Barakat. 2017. Effect of biofertilizer and humic, fulvic acids application on growth and productivity of corn plant (Zea mays L.). J. AlMuthanna Agric. Sci. 5 (1): 1-12.

Kamh, M and R.M. R. Hedia. 2018. NPK-Liquid Fertilizer Based on Humic-Like Substances Extracted from Spent Coffee Grounds: Extraction, Preparation and Application to Maize. Alex. Sci. Exch. J. 39: 260-267. 
ALEXANDRIA SCIENCE EXCHANGE JOURNAL, VOL. 42, No.4. OCTOBER- DECEMBER 2021

829

الملخص العربي

استجابة نمو ومحصول الذرة الثامية لمستويات مختلفة من حمض الهيوميك والزنتك

محمود أبوعجيلة على رحومة

لدراسة تأثير إضافة حضض الهيوميك والزنك على نمو معنوية فى نمو نباتات الذرة صنف Pioneer 3084 ومحصول وانتاجية الذرة الثامية- أجريت تجربة حقلية فى مزرعة الحبوب وصفات الكوز ومحتوى الحبة من البروتين - كما

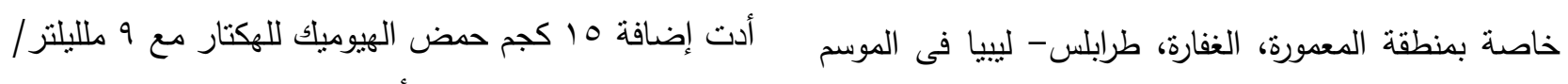

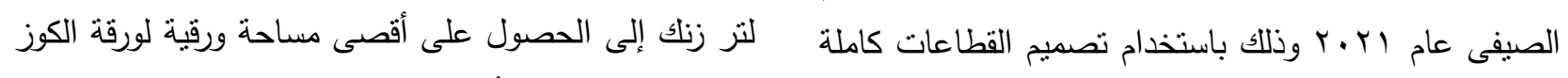

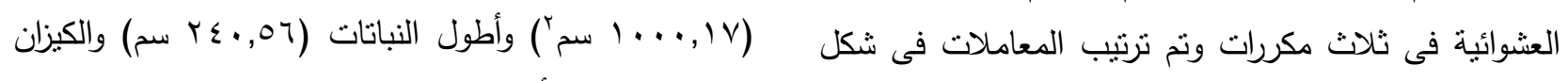

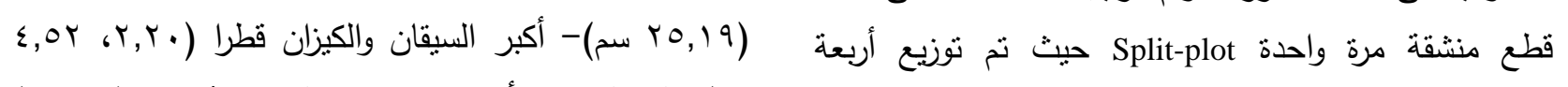

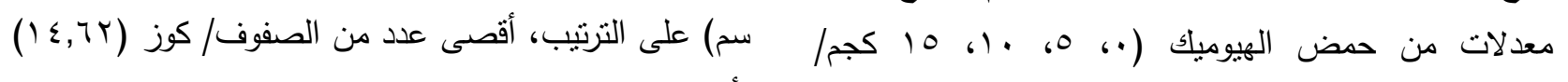

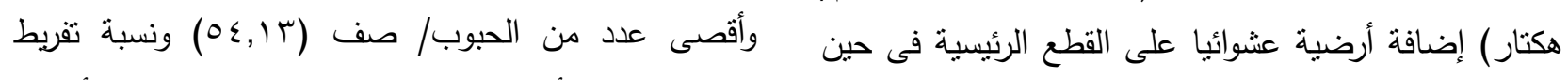

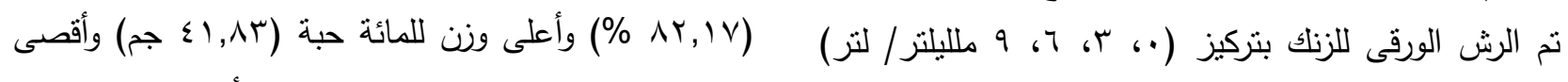

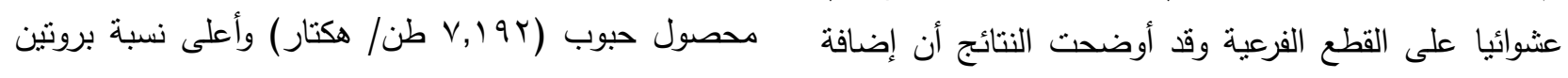

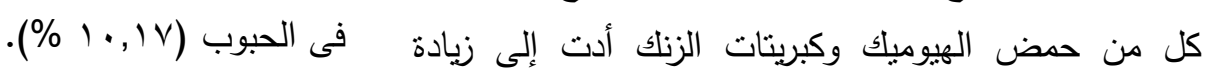

